\title{
Low concentrations of acetic and formic acids enhance the inactivation of Staphylococcus aureus and Pseudomonas aeruginosa with pulsed electric fields
}

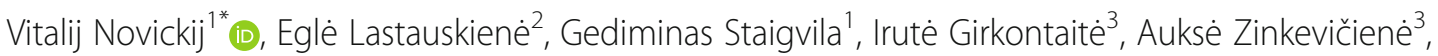 \\ Jurgita Švediené ${ }^{4}$, Algimantas Paškevičius ${ }^{4}$, Svetlana Markovskaja ${ }^{5}$ and Jurij Novickij ${ }^{1}$
}

\begin{abstract}
Background: Skin infections, particularly caused by drug-resistant pathogens, represent a clinical challenge due to being a frequent cause of morbidity and mortality. The objectives of this study were to examine if low concentrations of acetic and formic acids can increase sensitivity of Staphylococcus aureus and Pseudomonas aeruginosa to pulsed electric field (PEF) and thus, promote a fast and efficient treatment methodology for wound treatment.

Results: We have shown that the combination of PEF (10-30 kV/cm) with organic acids $(0.1 \%$ formic and acetic acids) increased the bactericidal properties of treatment. The effect was apparent for both acids. The proposed methodology allowed to reduce the energy of electrical pulses and the inhibitory concentrations of acids, while still maintain high efficiency of bacteria eradication.

Conclusions: Application of weak organic acids as bactericidal agents has many advantages over antibiotics because they do not trigger development of drug-resistance in bacteria. The combination with PEF can make the treatment effective even against biofilms. The results of this study are particularly useful for the development of new methodologies for the treatment of extreme cases of wound infections when the chemical treatment is no longer effective or hinders wound healing.
\end{abstract}

Keywords: Bacteria, Wound healing, Electroporation, Infection control, Electropermeabilization

\section{Background}

Skin infections, particularly caused by drug-resistant pathogens, represent a clinical challenge due to being a frequent cause of morbidity and mortality [1, 2]. The complications from the non-healing wounds may include septicemia, long-time hospitalization, chronic pain or limb amputations [3-6]. Burn wound infections are associated with even more severe complications and high mortality rates [7]. Multiple bacterial species can be responsible for burn wound infections, with the Staphylococcus aureus and Pseudomonas aeruginosa, being the most common $[4,8]$.

\footnotetext{
*Correspondence: vitalij.novickij@vgtu.lt

${ }^{1}$ Faculty of Electronics, Vilnius Gediminas Technical University, Naugarduko st. 41, 03227 Vilnius, Lithuania

Full list of author information is available at the end of the article
}

S. aureus is a major human pathogen, which will likely remain both common and serious due to the high environmental adaptability and development of resistance to antibiotics [9-11]. Infections due to $S$. aureus isolates with resistance to vancomycin have been associated with multiple treatment failures $[11,12]$. At the same time, $P$. aeruginosa can be associated with refractory skin ulcer, bacterial biofilm formation and resistivity to the majority of antimicrobials $[13,14]$. Since the biofilms are resistant to antibiotics and host defenses, targeting the pathogen with other antibacterial methods may be the only option to promote wound healing $[4,15]$. For example, application of antimicrobial peptides or synthesized nanoparticles could be considered [3, 16, 17]. However, most of the studies have focused on the research of chemical bactericidal agents, which are weak against biofilms, 
therefore physical methods started to emerge [13, 18, 19]. One of the methodologies, which has shown a high potential for wound sterilization and healing is electroporation [20-22]. The electroporation is a pulsed electric field (PEF) induced phenomenon, which triggers permanent or reversible permeability of cells to other molecules [23, 24]. The first studies, which highlighted the potential of electroporation for treatment of surface infections were published within the past 5 years, showing positive results for eradication of the skin infections causative microorganisms $[20,22,25,26]$. Currently, most of the studies on bacteria and yeast treatment with PEF are focused on protein extraction, food processing and transformation methods [27-29], while biomedical application are dominated by cancer treatment [30-33]. Therefore, application of PEF for wound sterilization is an emerging field, while PEF-based wound healing techniques have been proposed earlier [34, 35]. The main reason for the delay in the area of PEF wound sterilization could be the dependence of electroporation efficiency on the pulse parameters $[36,37]$. Bacteria and yeast are way more resistant to PEF if compared to mammalian cells, therefore higher requirements for development of pulse generators to trigger the electroporation phenomenon in prokaryotes is required [38-41]. However, with the development of the pulsed power technologies and increased availability of the electroporators, the first studies on the interactions of the bacterial cell wall and PEF started to appear [42]. Also, it was shown that the permeabilization of the bacteria membranes allowed restoring the sensitivity of pathogens to antimicrobial agents, which is of high relevance in the area of wound healing and treatment of the surface infections [16].

In this study, we focused on the inactivation efficiency of electroporation in a broad range of PEF amplitudes $\left(10-30 \mathrm{kVcm}^{-1}\right)$ for both the gram-positive $S$. aureus and gram-negative $P$. aeruginosa. Taking into account the recent advances in the understanding of bacteria cell wall interactions with PEF [42] and the varied susceptibility of bacteria to antimicrobials due to increased permeabilization [16], we have combined electroporation with weak organic acids (i.e. acetic and formic) in order to induce better inactivation. Acetic acid in low concentrations has already proven to be a potent antiseptic, especially when common antiseptics (hydrogen peroxide, iodine and alcohol) are toxic to the cells, which are involved in wound healing [43-45]. We presumed, that when combined with electroporation the methodology is very potent for treatment of burn wound infections, where both high inactivation efficiency and wound healing is required. The low concentration formic acid has been used as a reference due to its low toxicity [46]. Since electroporation is highly associated with reactive oxygen species and oxidation mechanisms [47-49], we wanted to test if the additive effect of acetic acid with PEF is apparent with other acids. The PEF induced cell permeabilization experiments have been performed in vitro and the inactivation efficiency was evaluated.

\section{Methods \\ Cultivation of bacterial cells and determination of minimal inhibitory concentrations of acids}

S. aureus (ATCC29213) and P. aeruginosa (ATCC27853) cells were grown over night in liquid LB (Luria-Bertani) medium $(10 \mathrm{~g} / \mathrm{l}$ tryptone, $5 \mathrm{~g} / \mathrm{l}$ yeast extract, $5 \mathrm{~g} / \mathrm{l} \mathrm{NaCl})$ in the rotary shaker at $37^{\circ} \mathrm{C} .1 \mathrm{ml}$ of the $\mathrm{OD}=1(600$ $\mathrm{nm} ; 1.5 \times 10^{9}$ cells) cell culture was transferred to $10 \mathrm{ml}$ of the fresh LB medium and grown $4 \mathrm{~h}$ at the same conditions. Later the cells were washed 3 times with $1 \mathrm{M}$ sorbitol and re-suspended in $1 \mathrm{M}$ sorbitol at final concentration of $10^{9}$.

The minimal inhibitory concentrations (MIC) of acetic and formic acid were determined by using agar diffusion and microdilution methods in 96-well microdilution plates. For agar diffusion, $S$. aureus and $P$. aeruginosa cells were subcultured on the LB agar medium at $37^{\circ} \mathrm{C}$. Cell suspensions were prepared using liquid LB medium $(\mathrm{OD}=1)$. Inocula were spread on solid agar and $3 \mathrm{~mm}$ holes were punched in the agar plates. 1, 0.5, 0.3, 0.2 and $0.1 \%$ of formic and acetic acids were added to the wells. Plates were analyzed individually by measuring the inhibition zone.

For the microdilution method, the cell suspension was prepared as described above and $100 \mu \mathrm{l}$ of the cell suspension was added to the $100 \mu \mathrm{l}$ of LB medium supplemented with the known concentrations of tested compounds. The $100 \mu \mathrm{l}$ of each bacteria suspension was added to the $100 \mu \mathrm{l} \mathrm{LB}$ medium as a positive control. Medium alone was used as a sterile control. Microplates were incubated at $37^{\circ} \mathrm{C}$ for $24 \mathrm{~h}$. The first 2 wells without visible growth were counted as MIC and plated on the $\mathrm{LB}$ agar plates at $37^{\circ} \mathrm{C}$ for $24 \mathrm{~h}$ as a reference.

All experiments were performed in triplicate.

\section{Electroporation}

The square wave electroporator capable of generating $100 \mathrm{~ns}-1 \mathrm{~ms}$ pulses up to $3 \mathrm{kV}$ was used in the study [50]. The commercial electroporation cuvette (VWR International, Radnor, PA, USA) with $1 \mathrm{~mm}$ gap between the electrodes was used as a load. For bacteria inactivation, the pulses were generated in bursts of 10 or 20 with a fixed duration of $100 \mu \mathrm{s}$, while for the permeabilization experiments, single $100 \mu$ s pulses were used. The PEF amplitude was varied in the range of $10-30 \mathrm{kVcm}^{-1}$, corresponding to $1-3 \mathrm{kV}$ voltage drop on the electroporation cuvette. Samples of $70 \mu \mathrm{L}$ of the cell suspension (prepared in $1 \mathrm{M}$ sorbitol) were used for electroporation. 
For combined PEF and chemical treatment, the $63 \mu \mathrm{L}$ of cell suspension was mixed with $7 \mu \mathrm{L}$ of $1 \%$ acid (either acetic or formic) resulting in a final $0.1 \%$ concentration. The resulting suspension was transferred to cuvette and the 10 or 20 pulses protocols were applied, followed by a 3-min incubation in room temperature.

\section{Flow cytometry}

The samples of the cell suspension $(63 \mu \mathrm{L})$ were mixed with $7 \mu \mathrm{L}$ propidium iodide (PI) (Sigma-Aldrich, Germany) at final concentration of $50 \mu \mathrm{M}$ [51] and transferred to electroporation cuvette for pulse application. After the pulsing, a 10-min incubation at room temperature was performed for passive dye diffusion, followed by flow cytometric analysis. The samples were analyzed by FlowSight (Amnis, Seattle, USA) flow cytometer. The fluorescent cells (PI permeable) were gated as permeabilized in accordance with standard gating strategy used in electroporation studies [51-53].

\section{Cell survival}

After electroporation, the $S$. aureus and $P$. aeruginosa cells were plated on LB agar. After $24 \mathrm{~h}$ of growth at $37^{\circ} \mathrm{C}$ the colony forming units (CFU) were counted. As a reference, the untreated control samples were used $\left(\mathrm{CFU}_{\mathrm{C}}\right)$. The inactivation efficiency was evaluated as a ratio between the treated sample $\left(\mathrm{CFU}_{\mathrm{T}}\right)$ and the control $\left(\mathrm{CFU}_{\mathrm{C}}\right)$ expressed as a percentage.

For the combined PEF and chemical treatment, firstly the MICs of acids were determined. Agar diffusion and microdilution showed a $0.2 \%$ MIC using both acids for both bacteria species. Therefore, we have used a smaller concentration of $0.1 \%$ (both for acetic and formic acid) to minimize the effect of timing during experiment. As a result, the induced inactivation effects purely due to chemical treatment were also minimized. After pulse application, the cells were incubated in room temperature for $3 \mathrm{~min}$ and plated on LB agar plates.

\section{Statistical analysis}

One-way analysis of variance (ANOVA; $P<0.05$ ) was used to compare the differences in efficiency between protocols. If ANOVA indicated a statistically significant result, Tukey HSD multiple comparison test was used $(P<0.05$ was considered statistically significant). The data was post-processed using OriginPro 8.5 software (OriginLab, Northhampton, MA, USA). All experiments have been performed at least in triplicate and all values are presented as mean \pm standard deviation.

\section{Results}

\section{Permeabilization of bacteria in pulsed electric field}

The permeabilization results of $S$. aureus and $P$. aeruginosa are presented in Fig. 1 . As expected, the gram-negative $P$.

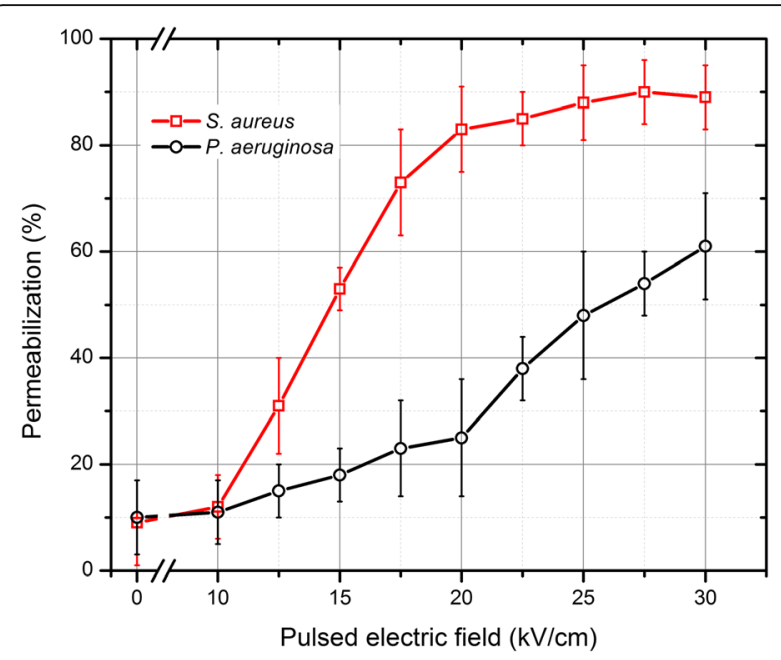

Fig. 1 The permeabilization of S. aureus and P. aeruginosa during pulsed electric field treatment. The $S$. aureus was more susceptible and the $20 \mathrm{kVcm}^{-1} \times 100 \mu$ s protocol induced a saturated (> 85\%) effect

aeruginosa was less susceptible to PEF if compared with the gram-positive $S$. aureus. The weaker effect of PEF on $P$. aueruginosa was apparent $(P<0.05)$ for all amplitudes in the $12.5-30 \mathrm{kVcm}^{-1}$ range. Even after $30 \mathrm{kVcm}^{-1}$ single $100 \mu$ s pulse less than $70 \%$ cells were permeable to PI, while the $S$. aureus reached a saturated permeabilization $(>85 \%)$ already after the $20 \mathrm{kVcm}^{-1}$ PEF treatment. The number of permeabilized cells in the control samples without any treatment did not exceed $10 \pm 8 \%$ for both bacteria.

\section{Survival of bacteria after electroporation}

The viability data on bacteria after PEF treatment are summarized in Fig. 2. It should be noted, that the permeabilization induced by single $100 \mu$ s pulse was reversible (effect on cell survival was negligible), therefore data for 10 and 20 pulses bursts are presented. As it can be seen in Fig. 2, the same tendency of $S$. aureus being more susceptible to treatment persists, however the difference in viability from $P$. aeruginosa was statistically significant only in the $20-30 \mathrm{kVcm}^{-1}$ range. More than $40 \%$ inactivation rate was achieved (S. aureus, $30 \mathrm{kVcm}^{-}$ ${ }^{1}$ ). We could have increased the total number of applied pulses and thus induce higher inactivation, however the goal was to detect additive effects with chemical agents. The reduction of viability in the $25-40 \%$ range was considered optimal and guaranteed high permeabilization of bacteria (see Fig. 1). We have applied the same inactivation protocols (10 and 20 pulses) in combination with low concentration of acids.

\section{Survival of bacteria after combined treatment with acids}

The results for acetic acid (0.1\%) are presented in Fig. 3. As it can be seen in Fig. 3 the inactivation rate was significantly higher for both bacteria when the PEF method 


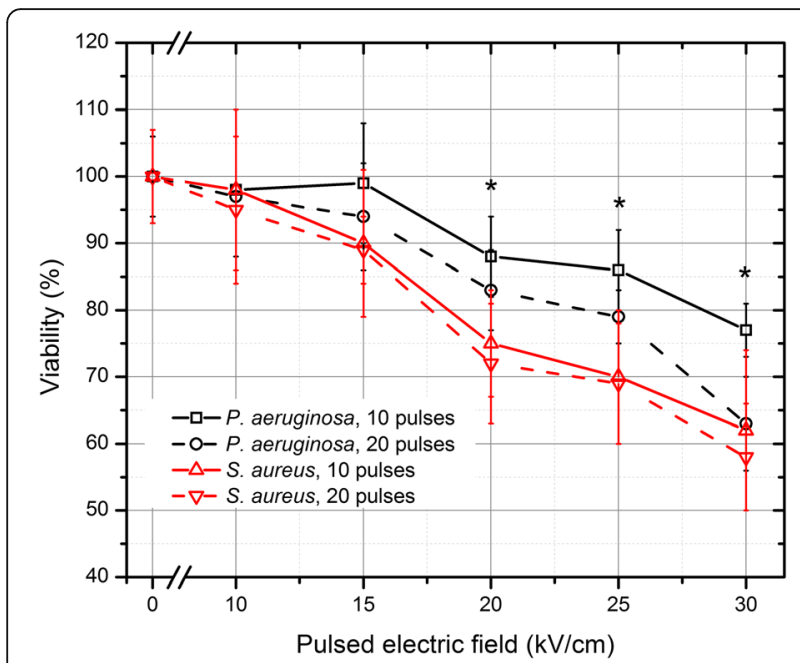

Fig. 2 The dependence of $S$. aureus and $P$. aeruginosa viability on the applied pulsed electric field parameters. Higher number of pulses resulted in higher loss of viability for both bacteria, however the effect was more profound $(P<0.05)$ in the $P$. aeruginosa case. The asterisk $\left(^{*}\right)$ represents statistically significant difference $(P<0.05)$ versus control (non-treated samples) for both bacteria

was applied in combination with low concentration $(0.1 \%)$ of acetic acid. The same methodology was applied with PEF and formic acid (0.1\%). The results are summarized in Fig. 4. It can be seen that a similar tendency of inactivation was also apparent. The $S$. aureus was more susceptible to the treatment, while the survival of bacteria was not affected $(P>0.05)$ by the $10 \mathrm{kVcm}^{-1}$ protocol.

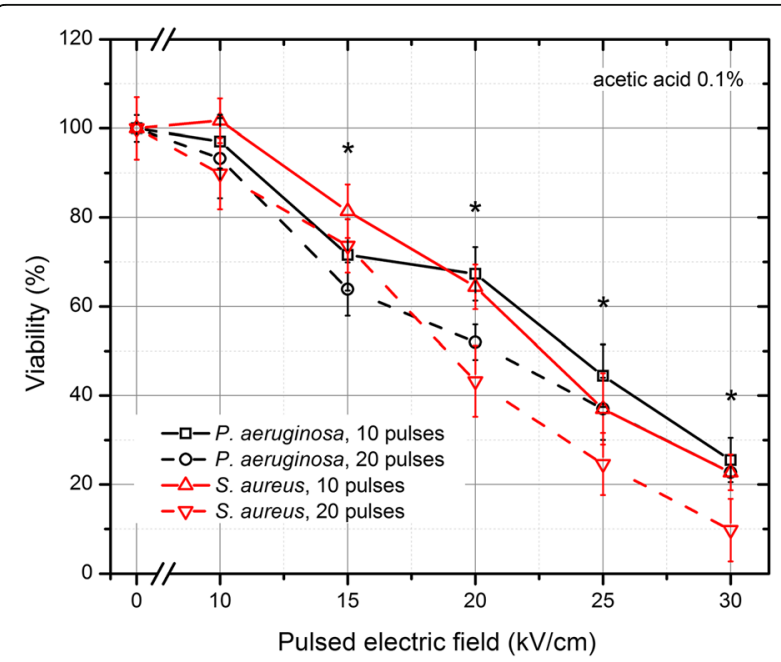

Fig. 3 The inactivation of bacteria using pulsed electric field treatment combined with acetic acid $(0.1 \%)$. The treatment was efficient for both bacteria, which was unachievable during separate exposures. The asterisk $(*)$ represents statistically significant difference $(P<0.05)$ versus control (chemical treatment only)

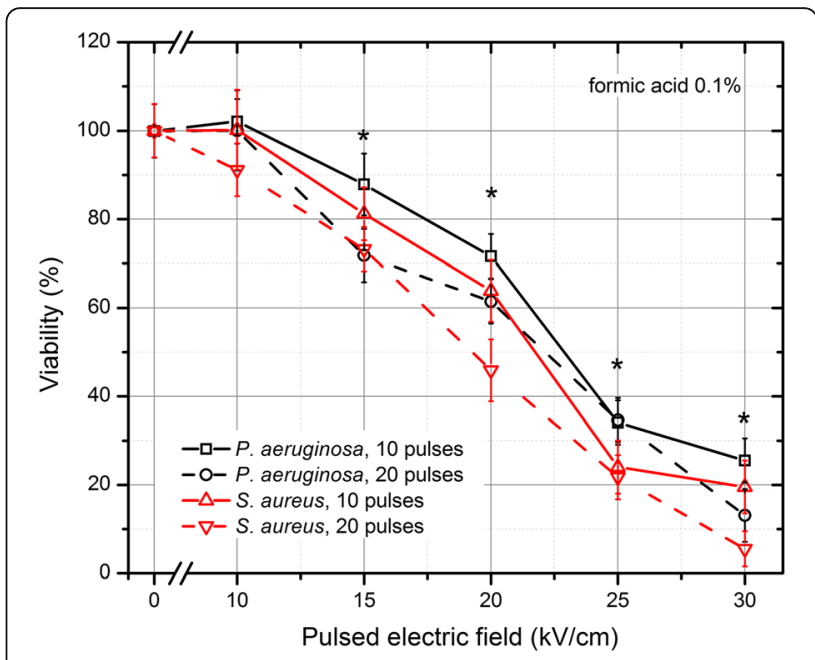

Fig. 4 The inactivation of bacteria using pulsed electric field treatment combined with acetic acid (0.1\%). The treatment was efficient for both bacteria, which was unachievable during separate exposures. The asterisk $\left(^{*}\right)$ represents statistically significant difference $(P<0.05)$ versus control (chemical treatment only)

The comparison of the most effective PEF protocols (20 pulses; $25-30 \mathrm{kVcm}^{-1}$ ) using both acids is presented in Fig. 5. The combination of chemical treatment with PEF resulted in a significant improvement of treatment efficiency for both bacteria. Also, there was statistically significant difference between $P$. aeruginosa and S. aureus susceptibility to the combined treatment for both acids (*). Formic acid on average was more potent than acetic acid resulting in almost full eradication of $S$. aureus when combined with PEF. The increase of bacteria

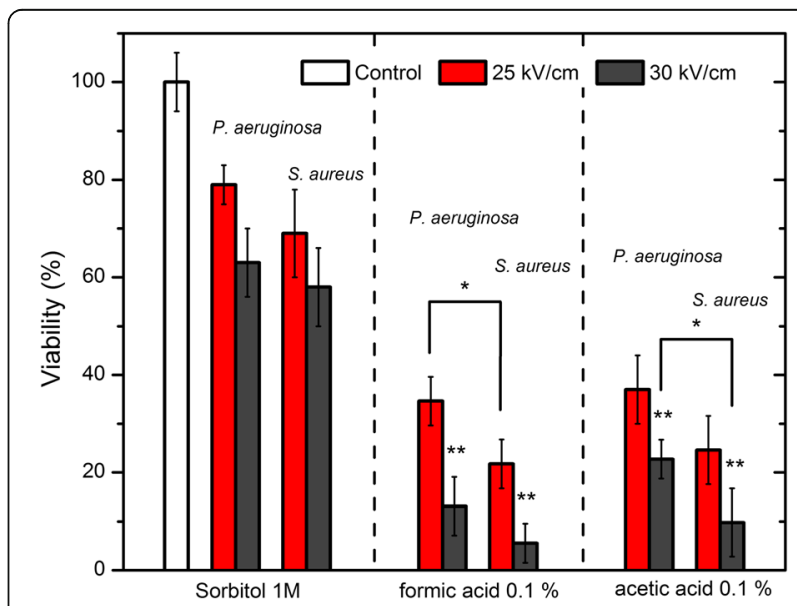

Fig. 5 The comparison of bacteria inactivation induced by the most effective protocols that were proposed in the study. The asterisk $\left(^{*}\right)$ represents statistically significant difference $(P<0.05)$ between $S$. aureus and $P$. aeruginosa. The asterisk $(* *)$ represents statistically significant difference $(P<0.05)$ between 25 and $30 \mathrm{kVcm}^{-1}$ procedures, which indicates that the effect is not saturated and can be enhanced 
membrane permeabilization by PEF induced sensitivity to the both acids, which was not detectable when acids were used in low concentrations.

\section{Discussion}

Application of weak organic acids as bactericidal agents has many advantages over antibiotics because they do not trigger development of drug-resistance in bacteria [43]. Concentrations $>2 \%$ have been frequently used to overcome infection in infected burn or chronic wounds both in animal and human models [45, 54]. Also in 2016, Golberg et al. successfully used electroporation to eradicate pathogenic bacteria in wounds [20] and it was also shown that it does not impair wound healing [35]. In our work, we have combined the two potent methodologies (electroporation and acids) and have shown that it is possible to further increase the sensitivity of bacteria to chemical agents.

The possible mechanism of the effect (bacteria sensitization) presumably lies within the drastic physical damage that is caused by PEF. The exposure to PEF triggers permeabilization of plasma membrane and disruption of the cell wall integrity [27, 42]. The cell wall is the main bacteria's barrier against environment and the cell wall-targeting antibiotics are a common solution to overcome the drug-resistivity when used in combination therapies [55, 56]. However, in the electroporation case it is a physical method, which is non-toxic and can be successfully used even for eradication of biofilms [22]. The combination of PEF with organic acids increased the bactericidal properties of treatment, which can be attributed to the internal $\mathrm{pH}$ shock, which was induced due to the high permeabilization of bacteria cell wall and uptake of acids [45, 54]. The effect was apparent for both acids (acetic and formic), which supports the hypothesis and is in agreement with previously observed effects in yeast [57]. Also, the oxidative stress and reactive oxygen species (ROS) may have significantly contributed to the lethality of the treatment $[58,59]$. The proof of concept that PEF can generate both extracellular (electrochemical) and intracellular ROS was reported before [49]. The increase of intracellular $\mathrm{O}_{2}$ can cause oxidative stress in bacteria, which is extremely harmful to microorganisms and a number of enzymes with active-site iron-sulfur clusters are highly sensitive to inactivation by $\mathrm{O}_{2}$ [59].

Nevertheless, electroporation is a pulse dependent phenomenon and the inactivation of bacteria solely by PEF may result in thermal damage of tissue, pain or muscle contractions [60,61], while high concentration of acid (>2\%) may cause significant pain $[45,54]$. In this work, we have used acid concentrations, which are below the minimal inhibitory dose, however the additive effect with PEF was still detectable. The result is of high relevancy since the bacteria sensitization phenomenon allows to reduce both the energy of electrical pulses and the concentration of acids, while still maintain high efficiency of bacteria eradication. Similar to Golberg et al., we have used microsecond pulses, however we have applied shorter bursts (lower number of pulses) for a faster procedure. It should be noted that microsecond range protocols $(10-30 \mathrm{kV} / \mathrm{cm})$ may result in high muscle contractions in vivo and due to different susceptibility of mammalian and bacterial cells to PEF, healthy tissue can be also affected [20]. Therefore, adopting of the proposed methodology in the nanosecond PEF range is more advantageous from the clinical perspective. The nanosecond range PEF protocols will allow reduction of the muscle contractions [62], ensure a more homogenous exposure [63] and better energy control [64]. The optimization of the protocols should be performed.

Firstly, the amplitude and/or duration of PEF pulses should be reduced to prevent/minimize damage of healthy tissue and muscle contractions, which was also highlighted by Golberg et al [20]. Further, the pulse delivery methodology can be altered. We believe, that the potential solution to the mentioned problems is to use the topical delivery of acetic acid to serve as a high impedance electrode/tissue interface and deliver the pulses using electrodes without forming a skin lump or keeping it minimal. The difference in load bioimpedances would result in only a thin layer of epidermis being affected, while the depth of ablation could be controlled by the bioimpedance of the electrode/tissue contact and by the amplitude of electric field [65]. In cases of wound treatment, the low penetration depth of PEF is advantageous, since it will allow to sustain the PEF effect predominantly in the infected volume. The problem and the requirement for penetration of deep tissues are specific for cancer treatment applications [66].

\section{Conclusions}

It was shown that electroporation in combination with acetic and formic acid triggers inactivation of $S$. aureus and $P$. aeruginosa. Taking into account the advantages of organic acids over antibiotics, the proposed methodology has high potential applicability. The results are useful as a starting point and as a proof of concept for the development of new PEF-based methods for the treatment of extreme cases of wound infections, especially when the chemical treatment is no longer effective or hinders wound healing. The future in vivo works should involve optimization of the PEF parameters and determination of the optimal acid concentration to ensure painless, fast and efficient procedure. Lastly, the efficacy of the PEF methodology for the treatment of biofilms should be investigated and is a matter of future works. 


\section{Acknowledgements}

Not applicable.

\section{Funding}

The research was funded by Research Council of Lithuania Towards Future Technologies programme grant Nr. LAT-02/2016. The funders had no role in study design, data collection and analysis, decision to publish, or preparation of the manuscript.

\section{Availability of data and materials}

The datasets used and/or analysed during the current study are available from the corresponding author on reasonable request.

\section{Authors' contributions}

VN supervised the work. VN, EL conceived the experiments and methodology. VN, GS, AZ, SM, JS have conducted experiments. VN, GS and JN have developed pulsed electric field systems. VN, EL, AP, IG processed, analyzed and interpreted the results. VN, EL, IG, AP, JN have wrote the manuscript. All authors reviewed and approved the final manuscript.

\section{Ethics approval and consent to participate}

Not applicable.

\section{Consent for publication}

Not applicable.

\section{Competing interests}

The authors declare that they have no competing interests.

\section{Publisher's Note}

Springer Nature remains neutral with regard to jurisdictional claims in published maps and institutional affiliations.

\section{Author details}

${ }^{1}$ Faculty of Electronics, Vilnius Gediminas Technical University, Naugarduko st 41, 03227 Vilnius, Lithuania. ${ }^{2}$ Institute of Biosciences, Life Sciences Centre, Vilnius University, Sauletekio al. 7, 10257 Vilnius, Lithuania. ${ }^{3}$ Department of Immunology, State Research Institute Centre for Innovative Medicine, Santariškių st. 5, 08406 Vilnius, Lithuania. ${ }^{4}$ Laboratory of Biodeterioration Research, Nature Research Centre, Akademijos st. 2, 08412 Vilnius, Lithuania. ${ }^{5}$ Laboratory of Mycology, Nature Research Centre, Žaliuju ežeru st. 49, 08406 Vilnius, Lithuania.

\section{Received: 5 February 2018 Accepted: 28 March 2019} Published online: 03 April 2019

\section{References}

1. Coban YK. Infection control in severely burned patients. World J Crit care Med. 2012;1:94-101.

2. $\quad$ Rice TC, Seitz AP, Edwards MJ, Gulbins E, Caldwell CC. Sphingosine rescues burn-injured mice from pulmonary Pseudomonas aeruginosa infection. Frontline Science. 2016;100:1233-7.

3. Santos R, Gomes D, Macedo H, Barros D, Tibério C, et al. Guar gum as a new antimicrobial peptide delivery system against diabetic foot ulcers Staphylococcus aureus isolates. J Med Microbiol. 2016;65:1092-9.

4. Trøstrup H, Thomsen K, Christophersen LJ, Hougen HP, Bjarnsholt T, et al. Pseudomonas aeruginosa biofilm aggravates skin inflammatory response in BALB/C mice in a novel chronic wound model. Wound Repair Regen. 2013; 21:292-9.

5. Dhamgaye S, Qu Y, Peleg AY. Polymicrobial infections involving clinically relevant gram-negative bacteria and fungi. Cell Microbiol. 2016:18:1716-22.

6. Potashman MH, Stokes M, Lu J, Lawrence R, Harris L. Examination of hospital length of stay in Canada among patients with acute bacterial skin and skin structure infection caused by methicillin-resistant Staphylococcus aureus. Infect Drug Resist. 2016;9:19-33.

7. Nitzschke SL, Aden JK, Serio-Melvin ML, Shingleton SK, Chung KK, et al. Wound healing trajectories in burn patients and their impact on mortality. J Burn Care Res. 2014;35:474-9.

8. Popov L, Kovalski J, Grandi G, Bagnoli F, Amieva MR. Three-dimensional human skin models to understand Staphylococcus aureus skin colonization and infection. Front Immunol. 2014;5:1-6.
9. Chambers HF, Deleo FR. Waves of resistance: Staphylococcus aureus in the antibiotic era. Nat Rev Microbiol. 2010;7:629-41.

10. Tong SYC, Davis JS, Eichenberger E, Holland TL, Fowler VG. Staphylococcus aureus infections: epidemiology, pathophysiology, clinical manifestations, and management. Clin Microbiol Rev. 2015;28:603-61.

11. Friães $A$, Resina C, Manuel V, Lito LM, Ramirez M, et al. Epidemiological survey of the first case of vancomycin-resistant Staphylococcus aureus infection in Europe. Epidemiol Infect. 2014;5:1-4.

12. Van Hal SJ, Fowler VG. Is it time to replace vancomycin in the treatment of methicillin-resistant Staphylococcus aureus infections? Clin Infect Dis. 2013; 56:1779-88

13. Lei $X$, Liu B, Huang Z, Wu J. A clinical study of photodynamic therapy for chronic skin ulcers in lower limbs infected with Pseudomonas aeruginosa. Arch Dermatol Res. 2015;307:49-55

14. Anvarinejad M, Japoni A, Rafaatpour N, Mardaneh J, Abbasi $P$, et al. Burn patients wounds infected with Metallo-Beta-lactamase-producing Pseudomonas aeruginosa: multidrug resistant strains. Arch Trauma Res. 2014;3:e18182.

15. Rybtke M, Hultqvist LD, Givskov M, Tolker-Nielsen T. Pseudomonas aeruginosa biofilm infections: community structure, antimicrobial tolerance and immune response. J Mol Biol. 2015:427:3628-45.

16. Ravensdale J, Wong Z, O'Brien F, Gregg K. Efficacy of antibacterial peptides against peptide-resistant mrsa is restored by permeabilization of bacteria membranes. Front Microbiol. 2016;7:1-10.

17. Palanisamy N, Ferina N, Amirulhusni A, Mohd-Zain Z, Hussaini J, et al. Antibiofilm properties of chemically synthesized silver nanoparticles found against Pseudomonas aeruginosa. J Nanobiotechnology. 2014;12:2.

18. Ermolaeva SA, Varfolomeev AF, Chernukha MY, Yurov DS, Vasiliev MM, et al. Bactericidal effects of non-thermal argon plasma in vitro, in biofilms and in the animal model of infected wounds. J Med Microbiol. 2011:60:75-83.

19. Liu Y, Zhou Q, Wang Y, Liu Z, Dong M, et al. Negative pressure wound therapy decreases mortality in a murine model of burn-wound sepsis involving pseudomonas aeruginosa infection. PLoS One. 2014;9:1-7.

20. Golberg A, Broelsch GF, Vecchio D, Khan S, Hamblin MR, et al. Pulsed electric fields for burn wound disinfection in a murine model. J Burn Care Res. 2016:36:7-13.

21. Novickij V, Grainys A, Švedienė J, Paškevičius A, Novickij J. Controlled inactivation of Trichophyton rubrum using shaped electrical pulse bursts: parametric analysis. Biotechnol Prog. 2016;32:1056-60.

22. Khan SI, Blumrosen G, Vecchio D, Golberg A, Mccormack MC, et al. Eradication of multidrug-resistant Pseudomonas biofilm with pulsed electric fields. Biotechnol Bioeng. 2016;113:643-50.

23. Tsong TYY. Electroporation of cell membranes. Biophys J. 1991;60:297-306.

24. Kotnik T, Kramar P, Pucihar G, Miklavčič D, Tarek M. Cell membrane electroporation - part 1: the phenomenon. IEEE Electr Insul Mag. 2012 28:14-23.

25. Novickij V, Grainys A, Lastauskiene E, Kananavičiute R, Pamedytyte D, et al. Growth inhibition and membrane permeabilization of Candida lusitaniae using varied pulse shape electroporation. Biomed Res Int; 2015. ID457896. doi:https://doi.org/10.1155/2015/457896.

26. Novickij V, Svediene J, Paskevicius A, Novickij J. In vitro evaluation of nanosecond electroporation against Trichophyton rubrum with or without antifungal drugs and terpenes. Mycoscience. 2017;8:6-11.

27. Haberl Meglic S, Marolt T, Miklavcic D. Protein extraction by means of electroporation from E. Coli with preserved viability. J Membr Biol. 2015;248:893-901.

28. Pillet F, Marjanovic I, Rebersek M, Miklavcic D, Rols MP, Kotnik T. Inactivation of spores by electric arcs. BMC Microbiol. 2016;16:148.

29. Kotnik T, Frey W, Sack M, Haberl Meglič S, Peterka M, et al. Electroporationbased applications in biotechnology. Trends Biotechnol. 2015:33:480-8.

30. Snoj M. Electrochemotherapy of tumors. Curr Oncol. 2009;16:34-5.

31. Wagstaff PGK, Buijs M, Bruin DM De, Zondervan PJ, Jmch J, et al. Irreversible electroporation : state of the art. Onco Targets Ther. 2016;9:2437-46.

32. Golberg A, Rubinsky B. Towards electroporation based treatment planning considering electric field induced muscle contractions. Technol Cancer Res Treat. 2012:11:189-201.

33. Miklavcic D, Davalos RV. Electrochemotherapy (ECT) and irreversible electroporation (IRE) -advanced techniques for treating deep-seated tumors based on electroporation. Biomed Eng Online. 2015;14:11.

34. Ferraro B, Cruz YL, Coppola D, Heller R. Intradermal delivery of plasmid VEGF (165) by electroporation promotes wound healing. Mol Ther. 2009;17:651-7. 
35. Ferguson $M$, Byrnes $C$, Sun L, Marti G, Bonde $P$, et al. Wound healing enhancement: electroporation to address a classic problem of military medicine. World J Surg. 2005;29:55-9.

36. Pucihar G, Krmelj J, Reberšek M, Napotnik TB, Miklavčič D. Equivalent pulse parameters for electroporation. IEEE Trans Biomed Eng. 2011;58:3279-88.

37. Rems L, Miklavčič D. Tutorial: Electroporation of cells in complex materials and tissue. J Appl Phys. 2016;119. Epub ahead of print. https://doi.org/10. 1063/1.4949264.

38. Reberšek M, Miklavčič D, Bertacchini C, Sack M. Cell membrane electroporationPart 3: The equipment. IEEE Electr Insul Mag. 2014;30:8-18.

39. Kotnik T, Pucihar G, Reberšek M, Miklavčič D, Mir LM. Role of pulse shape in cell membrane electropermeabilization. Biochim Biophys Acta Biomembr. 2003;1614:193-200.

40. Flisar K, Meglic SH, Morelj J, Golob J, Miklavcic D. Testing a prototype pulse generator for a continuous flow system and its use for $E$. coli inactivation and microalgae lipid extraction. Bioelectrochemistry. 2014;100:44-51.

41. Novickij V, Stankevic V, Grainys A, Novickij J, Tolvaisiene S. Microsecond electroporator optimization for parasitic load handling and damping. Elektron ir Elektrotechnika. 2015;21:40-3.

42. Pillet F, Formosa-Dague C, Baaziz H, Dague E, Rols M-P. Cell wall as a target for bacteria inactivation by pulsed electric fields. Sci Rep. 2016:6:19778.

43. Nagoba BS, Selkar SP, Wadher BJ, Gandhi RC. Acetic acid treatment of pseudomonal wound infections - a review. J Infect Public Health. 2013;6: 410-5.

44. Lineaweaver W, McMorris S, Soucy D, Howard R. Cellular and bacterial toxicities of topical antimicrobials. Plast Reconstr Surg. 1985;75:394-6.

45. Madhusudhan V. Efficacy of $1 \%$ acetic acid in the treatment of chronic wounds infected with Pseudomonas aeruginosa: prospective randomised controlled clinical trial. Int Wound J. 2016;13(6):1129-36.

46. Liesivuori J, Savolainen AH. Methanol and formic acid toxicity: biochemical mechanisms. Pharmacol Toxicol. 1991;69:157-63.

47. Vernier PT, Levine ZA, Wu YH, Joubert V, Ziegler MJ, et al. Electroporating fields target oxidatively damaged areas in the cell membrane. PLoS One. 2009;4:e7966

48. Venslauskas MS, Šatkauskas S. Mechanisms of transfer of bioactive molecules through the cell membrane by electroporation. Eur Biophys J. 2015;44:277-89.

49. Pakhomova ON, Khorokhorina VA, Bowman AM, Rodaite-Riseviciene R, Saulis G, et al. Oxidative effects of nanosecond pulsed electric field exposure in cells and cell-free media. Arch Biochem Biophys. 2012;527:55-64.

50. Novickij V, Grainys A, Butkus P, Tolvaišienè S, Švedienè J, et al. High-frequency submicrosecond electroporator. Biotechnol Biotechnol Equip. 2016;30:607-13.

51. Novickij V, Girkontaite I, Grainys A, Zinkevičiene A, Lastauskiene E, et al. Measurement of transient permeability of Sp2/0 myeloma cells: flow cytometric study. Meas Sci Rev. 2016;16:300-4.

52. Michie J, Janssens D, Cilliers J, Smit BJ, Böhm L. Assessment of electroporation by flow cytometry. Cytometry. 2000;41:96-101.

53. Novickij V, Ruzgys P, Grainys A, Šatkauskas S. High frequency electroporation efficiency is under control of membrane capacitive charging and voltage potential relaxation. Bioelectrochemistry. 2018;119:92-7.

54. Bitsch M, Saunte DM, Lohmann M, Holstein PE, Jørgensen B, et al Standardised method of surgical treatment of chronic leg ulcers. Scand J Plast Reconstr Surg Hand Surg. 2005;39:162-9.

55. Nikolaidis I, Favini-Stabile S, Dessen A. Resistance to antibiotics targeted to the bacterial cell wall. Protein Sci. 2014;23:243-59.

56. Pucci MJ, Bush K. Investigational antimicrobial agents of 2013. Clin Microbiol Rev. 2013:26:792-821.

57. Novickij V, Švedienè J, Paškevičius A, Markovskaja S, Girkontaitė I, et al. Pulsed electric field-assisted sensitization of multidrug-resistant Candida albicans to antifungal drugs. Future Microbiol. 2018;13:535-46.

58. Zhao X, Drlica K. Reactive oxygen species and the bacterial response to lethal stress. Curr Opin Microbiol. 2014;21:1-6.

59. Cabiscol E, Tamarit J, Ros J. Oxidative stress in bacteria and protein damage by reactive oxygen species. Int Microbiol. 2000;3:3-8.

60. Davalos RV, Mir LM, Rubinsky B. Tissue ablation with irreversible electroporation. Ann Biomed Eng. 2005;33:223-31.

61. Arena CB, Sano MB, Rossmeisl JH, Caldwell JL, Garcia PA, et al. Highfrequency irreversible electroporation (H-FIRE) for non-thermal ablation without muscle contraction. Biomed Eng Online. 2011;10:102.

62. Mi Y, Xu J, Tang $X$, Bian C, Liu H, Yang Q, Tang J. Scaling relationship of in vivo muscle contraction strength of rabbits exposed to high-frequency nanosecond pulse bursts. Technol Cancer Res Treat. 2018:17: 1533033818788078. https://www.ncbi.nlm.nih.gov/pubmed/30012058.
63. Breton M, Mir LM. Microsecond and nanosecond electric pulses in cancer treatments. Bioelectromagnetics. 2012:33:106-23.

64. Guionet A, Joubert-Durigneux V, Packan D, Cheype C, Garnier JP, David F, Zaepffel C, Leroux RM, Teissié J, Blanckaert V. Effect of nanosecond pulsed electric field on Escherichia coli in water: inactivation and impact on protein changes. J Appl Microbiol. 2014;117:721-8.

65. Novickij $V$, Zinkevičienè A, Perminaitè $E$, Čèsna R, Lastauskienė $E$, et al. Noninvasive nanosecond electroporation for biocontrol of surface infections: an in vivo study. Sci Rep. 2018:8:14516.

66. Neal RE, Singh R, Hatcher HC, Kock ND, Torti SV, Davalos RV. Treatment of breast cancer through the application of irreversible electroporation using a novel minimally invasive single needle electrode. Breast Cancer Res Treat. 2010;123:295-301
Ready to submit your research? Choose BMC and benefit from:

- fast, convenient online submission

- thorough peer review by experienced researchers in your field

- rapid publication on acceptance

- support for research data, including large and complex data types

- gold Open Access which fosters wider collaboration and increased citations

- maximum visibility for your research: over $100 \mathrm{M}$ website views per year

At BMC, research is always in progress.

Learn more biomedcentral.com/submissions 